\begin{tabular}{|l|l|l||}
\hline \multicolumn{2}{|c|}{ PublisherInfo } \\
\hline \hline PublisherName & $:$ & BioMed Central \\
\hline \hline PublisherLocation & $:$ & London \\
\hline \hline PublisherImprintName & $:$ & BioMed Central \\
\hline \hline
\end{tabular}

\title{
Transgene transfer
}

\begin{tabular}{|l|l|l||}
\hline \multicolumn{2}{|c|}{ ArticleInfo } \\
\hline \hline ArticleID & $:$ & 4267 \\
\hline \hline ArticleDOI & $:$ & $10.1186 /$ gb-spotlight-20011130-01 \\
\hline \hline ArticleCitationID & $:$ & spotlight-20011130-01 \\
\hline \hline ArticleSequenceNumber & $:$ & 338 \\
\hline \hline ArticleCategory & $:$ & Research news \\
\hline \hline ArticleFirstPage & $:$ & 1 \\
\hline \hline ArticleLastPage & $:$ & 2 \\
\hline \hline & & RegistrationDate : 2001-11-30 \\
ArticleHistory & $:$ & OnlineDate \\
\hline \hline ArticleCopyright & $:$ & BioMed Central Ltd2001 $11-30$ \\
\hline \hline ArticleGrants & $:$ & \\
\hline \hline ArticleContext & $:$ & 130592211 \\
\hline \hline
\end{tabular}




\section{Jonathan B Weitzman}

Email: jonathanweitzman@hotmail.com

The use of genetically-modified crops has generated concern about the safety of transgenic plants and about the potential for gene flow to related wild species. In the November 29 Nature, David Quist and Ignacio Chapela from the University of California, Berkeley report evidence for the presence of introgressed transgenic DNA in maize plants grown in the remote Mexican mountains of Oaxaca (Nature 2001, 414:541-543). They collected cobs of native landraces of maize from different locations in the Sierra Norte de Oaxaca in Southern Mexico, and screened for the presence of transgenic DNA, using PCR to amplify a region of the $35 \mathrm{~S}$ promoter from cauliflower mosaic virus (CMV). They could amplify a DNA fragment in five of the seven Mexican wild maize samples, and also found other transgenic plant marker genes in some samples. Quist and Chapela also performed inverse PCR to characterize genomic DNA flanking the integrated CMV sequences. The transgene insertions were varied, indicating that introgression events are relatively common. This study presents evidence for gene flow from commercial, genetically modified maize to wild landrace populations and suggests that the effects on native agro-ecosystems should be carefully monitored.

\section{References}

1. When transgenes wander, should we worry?

2. Nature, [http://www.nature.com]

3. University of California, Berkeley, [http://www.berkeley.edu] 